\title{
ANALISIS SALURAN PEMASARAN BIJI KOPI ROBUSTA (Suatu Kasus di Desa Purwaraja Kecamatan Rajadesa Kabupaten Ciamis)
}

\author{
APAN APANDI ${ }^{*}$, TRISNA INSAN NOOR ${ }^{2}$, DANI LUKMAN HAKIM ${ }^{1}$ \\ ${ }^{1}$ Fakultas Pertanian Universitas Galuh \\ ${ }^{2}$ Fakultas Pertanian Universitas Padjajaran \\ *E-mail: apandiapan637@gmail.com
}

\begin{abstract}
ABSTRAK
Penelitian ini bertujuan untuk mengetahui : (1) Saluran pemasaran kopi robusta di Desa Purwaraja Kecamatan Rajadesa Kabupaten Ciamis; (2) Besarnya marjin, biaya dan keuntungan pemasaran kopi robusta di Desa Purwaraja Kecamatan Rajadesa Kabupaten Ciamis; (3) Besarnya bagian harga (farmer's share) yang diterima petani keseluruhan harga yang di bayar oleh konsumen. (4) Besarnya efisiensi pemasaran biji kopi robusta di Desa Purwaraja Kecamatan Rajadesa Kabupaten Ciamis. Jenis penelitian yang digunakan dalam penelitian ini adalah survey di Desa Purwaraja Kecamatan Rajadesa Kabupaten Ciamis. Survey merupakan teknik riset dimana informasi dikumpulkan menggunakan penyebaran kuesioner. Jumlah responden dalam penelitian ini sebanyak 32 orang. Dua puluh tujuh orang petani, dua orang pedagang pengumpul, satu orang pedagang besar, dan dua orang konsumen industri. Hasil penelitian Biiji Kopi Robusta di Desa Purwaraja Kecamatan Rajadesa Kabupaten Ciamis diketahui bahwa : 1) Terdapat dua saluran pemasaran biji kopi robusta sampai ke tangan konsumen akhir yaitu: a) Pola Saluran Pemasaran I : Petani---Pedagang Besar---Konsumen Industri, b) Pola Saluran II : Petani---Pedagang Pengumpul---Pedagang Besar---Konsumen Industri. 2) Besarnya Marjin, biaya, dan keuntungan pemasaran pada saluran pemasaran I sebagai berikut : (1) marjin pemasaran sebesar Rp 2.000 per kilogram (2) Biaya pemasaran sebesar Rp 1.010 per kilogram dan (3) keuntungan pemasaran sebesar Rp 990 per kilogram. Sedangkan marjin, biaya, dan keuntungan pada saluran pemasaran II sebagai berikut : (1) marjin pemasaran sebesar Rp 3.000 per kilogram (2) biaya pemasaran sebesar Rp 1.590 per kilogram, dan (3) keuntungan pemasaran sebesar Rp 1.410 per kilogram. 3) Berdasarkan hasil penghitungan bahwa besarnya nilai farmer's share atau bagian harga yang diterima petani pada saluran pemasaran I adalah 90,47 persen dan pada saluran pemasaran II sebesar 85,71 persen. 4) Besarnya efisiensi pemasarannya pada saluran pemasaran I sebesar 4,80 persen. Sedangkan pada saluran pemasaran II efisiensi pemasarannya sebesar 7,57 persen.
\end{abstract}

Kata Kunci : Biji, Kopi, Pemasaran, Robusta.

\begin{abstract}
This study aimed to know (1) The marketing channels of robusta coffee beans . (2) The margins, costs, profit, and marketing of robusta coffee beans. (3) Farmer's Share of robusta coffee beans. (4) The amount of marketing efficiency of robusta coffee beans. This research, method was case study in the Village District of Purwaraja Rajadesa, Ciamis regency. The number of respondents in the study were 32 persons. The result of the study showed that : 1) There were two robusta coffee beans marketing channels to industrial consument end, a) Channel I was : Farmer---Wholesaleres---Consumers Industries, and b) Channel II was : Farmer---Collectors---Wholesaleres---Consumers Industries. 2)The amount of costs, profit margins and marketing on marketing channels I as following : (1) Marketing margin of Rp 2.000 per kilogram, (2) Marketing expenses of Rp 1.010 per kilogram, and (3) The marketing
\end{abstract}


advantages of Rp 990 per kilogram. Meanwhile, costs margins and profits in the marketing channel II as following. (1) marketing margin of Rp 3.000 per kilogram, (2) Marketing expenses of $R p 1.590$ per kilogram, and (3) The marketing advantages of Rp 1.410 per kilogram. 3) Bases on the results or the farmer's share in marketing channel I was 90,00\% and in the channel II was 85,71 \%. 4) Marketing efficiency marketing channel I was 4,80 percent. While in the marketing channel II and marketing efficiency was 7,57 percent.

Keywords : Coffee, Marketing, Robusta, Seeds.

\section{PENDAHULUAN}

Sektor pertanian tampaknya masih menjadi primadona perekonomian di Indonesia. Meskipun telah terjadi transformasi struktur ekonomi dimana perekonomian negara lebih ditopang pada sektor industri dan jasa, namun sektor pertanian masih tetap mampu menyerap sebagian besar tenaga kerja (Badan Intelijen Negara, 2012). Salah satu subsektor pertanian yang memegang peranan besar untuk produk ekspor Indonesia ialah subsektor perkebunan.

Komoditas kopi merupakan produk budidaya perkebunan yang paling banyak diperdagangkan di dunia. Salah satu negara yang menjadi produsen dan eksportir kopi utama di dunia adalah Indonesia. Sampai tahun 2017, negara Indonesia adalah produsen kopi terbesar ketiga di dunia setelah Brazil dan Vietnam. Meskipun mengalami pasang surut nilai ekspor kopi Indonesia selalu berada pada lingkaran lima besar dunia. Selain itu bagi Indonesia kopi juga menjadi penyumbang devisa sektor perkebunan terbesar kedua setelah kelapa sawit (FAO, dalam Karya Tani Mandiri, 2018 : 2).

Salah satu sumber daya alam yang memiliki nilai ekonomis adalah komoditas kopi. Jika hasil dari komoditas kopi dapat dimanfaatkan oleh industri dengan baik, maka akan menghasilkan industri berbasis sumber daya berpotensi yang dapat meningkatkan cadangan devisa serta penyediaan lapangan kerja. Kopi sebagai salah satu komoditi ekonomis dikenal sebagai bahan minuman yang sudah tidak asing lagi. Aromanya yang harum, rasanya yang khas, serta khasiatnya yang dapat memberikan kesegaran bagi tubuh, membuat kopi cukup akrab dilidah dan digemari oleh masyarakat (Kadir, 2005).

Berdasarkan data Direktorat Jenderal Perkebunan (2015) produksi kopi Indonesia hingga tahun 2017 didominasi oleh $81,87 \%$ kopi jenis robusta yang 95,56\% diusahakan oleh sebagian besar perkebunan milik rakyat (PR) atau berkontribusi terhadap rata-rata produksi kopi mencapai 515,21 ribu ton. Dominasi kopi robusta yang cenderung lebih cepat 
berkembang dibandingkan kopi arabika tidak terlepas dari sejarah perkembangan kopi Indonesia.

Berdasarkan hasil Survei Sosial Ekonomi Nasional (SUSENAS) oleh BPS, permintaan kopi untuk konsumsi rumah tangga pada umumnya berupa kopi bubuk/kopi biji. Pada tahun 2002, konsumsi kopi per kapita per tahun sebesar $1,29 \mathrm{~kg} / \mathrm{kapita} / \mathrm{tahun}$ dan mengalami penurunan hingga 32,93\% pada tahun 2016 atau menjadi konsumsi 0,871 $\mathrm{kg} / \mathrm{kapita} / \mathrm{tahun}$ pada tahun 2016. Selama periode tersebut, penurunan konsumsi kopi tertinggi terjadi di tahun 2015 sebesar $33,51 \%$, dari 1,347 kg/kapita/tahun di tahun 2014 menjadi 0,896 kg/kapita/tahun di tahun 2015.

Menurut Dinas Perkebunan (2017), kebutuhan masyarakat Jawa Barat akan permintaan konsumsi kopi mencapai 90 ribu ton setiap tahunnya, baik berupa kopi biji atau kopi bubuk.

Kabupaten Ciamis adalah salah satu daerah yang mengembangkan perkebunan kopi di Provinsi Jawa Barat dan memiliki potensi sangat tinggi yang tersebar di berbagai kecamatan. rata-rata luas areal tanaman kopi robusta di Kabupaten Ciamis yaitu 68,58 hektar, rata-rata luas areal menghasilkan yaitu 31,67 hektar dengan produksi rata-rata sebanyak 26,32 ton dan rata-rata produktivitas sebesar 0,81 ton per hektar per tahun.

Kecamatan Rajadesa adalah salah satu penghasil kopi robusta terbesar di Kabupaten Ciamis dengan luas areal tanaman 384,40 hektar, luas areal menghasilkan 113,40 hektar dengan produksi sebesar 98,66 ton dan produktivitas sebesar 0,87 ton per hektar per tahun.

Desa Purwaraja merupakan salah satu desa sentra penghasil kopi robusta di Kecamatan Rajadesa dengan produksi ke empat terbesar setelah Desa Tigaherang, walaupun demikian hasil produksi biji kopi robusta di Desa Purwaraja mempunyai kualitas produksi yang paling baik jika dibandingkan dengan desa lain yang ada di Kecamatan Rajadesa. Hal ini dapat dilihat dari kadar air biji kopi kering yang sangat memenuhi kriteria pasar.

Keberhasilan kegiatan usahatani termasuk dalam kegiatan usahatani kopi robusta tidak saja ditentukan dengan tingginya angka produksi kopi robusta yang dihasilkan, namun sangat ditentukan pula oleh aspek pemasaran produk, karena peningkatan produksi kopi robusta tidak akan efektif bagi peningkatan pendapatan dan kesejahteraan petani dan masyarakat jika tidak diimbangi oleh sistem pemasaran. 
Pemasaran kopi robusta mempunyai pengaruh terhadap pendapatan petani karena terkait tingkat harga yang diterima petani. Pemasaran yang tidak efisien, rantai pemasaran yang terlau panjang, sarana dan prasarana transportasi yang kurang memadai, sistem kelembagaan pemasaran yang tidak sehat merupakan masalah-masalah pemasaran yang pada umumnya berpengaruh terhadap tingkat harga yang diterima petani.

Berdasarkan latar belakang maka dilakukan penelitian dengan judul

\section{"ANALISIS SALURAN PEMASARAN BIJI KOPI ROBUSTA (Coffea} canephora)" yang merupakan suatu kasus di Desa Purwaraja Kecamatan Rajadesa Kabupaten Ciamis.

\section{METODE PENELITIAN}

Metode penelitian yang digunakan adalah penelitian kualitatif. Menurut Sugiyono (2018), metode penelitian kualitatif adalah metode penelitian yang berlandaskan pada filsafat postpositivisme atau enterpretif, digunakan untuk meneliti pada kondisi obyek yang alamiah, di mana peneliti adalah sebagai instrumen kunci, teknik pengumpulan data dilakukan secara trianggulasi (gabungan observasi, wawancara, dokumentasi), data yang diperoleh cenderung data kualitatif, analisis data bersifat induktif/kualitatif, dan hasil penelitian kualitatif bersifat untuk memahami makna, memahami keunikan, mengkonstruksi fenomena, dan menemukan hipotesis.

Jenis penelitian yang digunakan dalam penelitian ini adalah survei pada petani kopi robusta di Desa Purwaraja Kecamatan Rajadesa Kabupaten Ciamis.

Menurut Wibisono (2005), survei merupakan teknik riset dimana informasi dikumpulkan menggunakan penyebaran kuesioner.

\section{Teknik Penarikan Sampel}

Teknik penarikan sampel penelitian untuk petani kopi robusta ini adalah secara sampling jenuh atau sensus, artinya semua petani kopi robusta dijadikan responden. Seluruh petani kopi robusta di Desa Purwaraja sebanyak 27 orang. Menurut Sugiyono (2011), sampling jenuh atau sensus dilakukan karena jumlah populasi relatif kecil atau kurang dari 30 orang, sehingga semua anggota populasi dijadikan sampel.

Penentuan sampel lembaga pemasaran dilakukan dengan menggunakan metode snowball sampling yaitu cara pengambilan sampel yang pada mulanya menggunakan sejumlah kecil sampel kemudian secara berjenjang 
bertambah hingga sampel yang diambil menjadi besar. Metode snowball sampling dipakai dalam penelitian ini, karena memungkinkan peneliti untuk menemukan rangkaian saluran pemasaran biji kopi robusta mulai dari petani sampai konsumen akhir. Pelaksanaan metode ini dengan menentukan petani sebagai lembaga pemasaran tingkat pertama, kemudian mengikuti aliran produk biji kopi robusta dari petani sampai konsumen akhir (Sugiyono, 2010).

\section{Rancangan Analisis Data}

Data yang diperoleh kemudian ditabulasi, lalu dianalisis secara deskriptif untuk mengetahui saluran pemasaran biji kopi robusta di Desa Purwaraja. Untuk mengetahui biaya pemasaran, marjin pemasaran, keuntungan pemasaran dan farmer's share dihitung dengan rumus sebagai berikut:

1. Biaya pemasaran adalah biaya yang dikeluarkan untuk memasarkan suatu komoditas dari produsen ke konsumen (Handayani dan Nurlaila, 2011).

$$
\mathrm{Bp}=\mathrm{Bp} 1+\mathrm{Bp} 2+\mathrm{Bp} 3+. .+\mathrm{Bpn}
$$

Keterangan :

Bp : Biaya pemasaran

Bp1,2,3..n : Biaya pemasaran tiap lembaga pemasaran

1,2,3...n : Jumlah lembaga
2. Marjin pemasaran adalah selisih harga tingkat produsen dan tingkat konsumen akhir (Handayani, 2011).

$\mathrm{M}=\mathrm{Pr}-\mathrm{Pf}$.

Marjin yang diperoleh pedagang perantara dari sejumlah biaya pemasaran yang dikeluarkan dan keuntungan yang diterima oleh pedagang perantara dirumuskan sebagai berikut:

$\mathrm{M}=\mathrm{Bp}+\mathrm{Kp}$

Keterangan :

Pr : Harga di tingkat konsumen

Pf : Harga di tingkat produsen

M : Marjin pemasaran

$\mathrm{Kp}$ : Keuntungan pemasaran

$\mathrm{Bp}$ : Biaya pemasaran

3. Keuntungan pemasaran adalah penjumlahan dari keuntungan yang diterima oleh setiap lembaga pemasaran (Handayani dan Nurlaila, 2011).

$\mathrm{Kp}=\mathrm{Kp} 1+\mathrm{Kp} 2+\mathrm{Kp} 3+. .+\mathrm{Kpn}$

Keterangan :

Kp : Keuntungan pemasaran

Kp1,2,3...n :Keuntungan pemasaran tiap lembaga pemasaran

1,2,3...n : jumlah lembaga

4. Farmer's share

Untuk mengetahui bagian harga yang diterima petani (farmer's share) 
menggunakan rumus :

$F S=\frac{\mathrm{pf}}{\mathrm{pr}} \times 100 \%$

Keterangan :

FS : bagian harga yang diterima produsen (Farmer's Share)

Pf : harga ditingkat petani $(\mathrm{Rp} / \mathrm{kg})$

Pr : harga akhir di tingkat lembaga pemasaran $(\mathrm{Rp} / \mathrm{kg})$

5. Efisiensi Pemasaran

Untuk menghitung efisiensi

pemasaran dapat menggunakan rumus:

$\mathrm{EP}=\frac{\mathrm{TB}}{\mathrm{TNP}} \times 100 \%$

Keterangan :

$\mathrm{EP}=$ Efisiensi pemasaran

$\mathrm{TB}=$ Total biaya pemasaran

$\mathrm{TNP}=$ Total nilai produk

Menurut Rosmawati (2011) efisien atau tidaknya pemasaran dapat dilihat dari seberapa besarnya nilai EP (Efisiensi Pemasaran) dalam saluran pemasaran tersebut.

$\mathrm{EF}=0-33 \% \longrightarrow$ Efisien

$\mathrm{EF}=34-67 \% \longrightarrow$ Kurang Efisien

$\mathrm{EF}=68-100 \% \longrightarrow$ Tidak Efisien

\section{HASIL DAN PEMBAHASAN}

\section{Identitas Responden}

Umur

umur rata-rata petani responden di

Desa Purwaraja terbilang masih produktif yaitu berada dikisaran 15-64 tahun. Hanya ada 5 petani responden yang sudah melewati umur produktif yaitu lebih dari 64 tahun. sedangkan umur rata-rata pedagang pengumpul, pedagang besar, dan konsumen industri semuanya masih produktif yaitu berada dikisaran umur 1564 tahun.

Jumlah Tanggungan Keluarga Responden

Jumlah responden yang mempunyai tanggungan keluarga 1-3 orang sebanyak 29 orang atau 82,85 persen, dan responden yang memiliki tanggungan keluarga 4 sampai 6 orang sebanyak 6 orang atau 17,14 persen.

\section{Keadaan Responden Berdasarkan} Tingkat Pendidikan

Tingkat pendidikan responden di Desa Purwaraja masih tergolong rendah yaitu lulusan SD sebanyak 25 orang atau 79,00 persen, lulusan SMP sebanyak 3 orang atau 10,00 persen, lulusan SMA sebanyak 2 orang atau 7,00 persen, dan lulusan SMK sebanyak 1 orang atau 4,00 persen.

\section{Pengalaman Responden dalam Usaha Kopi Robusta}

Responden dalam berusaha kopi robusta di Desa Purwaraja sudah memiliki pengalaman usaha yang cukup lama. Hal ini ditunjukkan dengan jumlah responden 
yang berusaha kopi robusta antara 1-15 tahun sebanyak 23 orang atau 71,875 persen, responden yang berusaha kopi robusta antara 16-30 tahun sebanyak 7 orang atau 21,875 persen, dan responden yang berusaha kopi robusta antara 31 tahun lebih sebanyak 3 orang atau 6,25 persen dari total jumlah responden.

\section{Luas Lahan Tanaman Kopi Robusta}

luas lahan yang digunakan antara 0,01 sampai 0,05 hektar sebanyak 9 orang atau 33,33 persen, luas lahan yang digunakan antara 0,06 sampai 0,10 hektar sebanyak 15 orang atau 55,55 persen, luas lahan yang digunakan lebih dari 0,10 hektar sebanyak 3 orang atau 11,11 persen dari jumlah petani responden.

\section{Kegiatan Lembaga Pemasaran}

Dalam penelitian ini lembaga pemasaran yang terlibat dalam proses penyampaian komoditas kopi dari petani ke konsumen, baik konsumen yang berada di luar kota maupun di dalam kota yaitu :

\section{Kegiatan di Tingkat Pedagang Pengumpul}

Untuk pedagang pengumpul responden dalam penelitian ini terdapat dua pedagang pengumpul yang berada di Desa Purwaraja dan di Desa Tigaherang Kecamatan Rajadesa. Pedagang pengumpul mendapatkan hasil biji kopi robusta dari setiap Desa yang berada di
Kecamatan Rajadesa. Jadi dalam hal ini pedagang pengumpul responden tidak hanya mendapatakan biji kopi robusta dari Desa Purwaraja dan Desa Tigaherang itu sendiri untuk mencukupi kebutuhan pasarnya, akan tetapi pedagang pengumpul mendapatkan biji kopi robusta dari Desadesa yang berada di Kecamatan Rajadesa.

Proses pemasaran pada saluran pemasaran I yaitu pedagang besar membeli biji kopi robusta langsung dari petani, kemudian pedagang besar langsung menjualnya ke konsumen industri d idalam kota maupun di luar kota. Sedangkan untuk pola saluran pemasaran II pedagang pengumpul membeli langsung biji kopi robusta dari petani, kemudian pedagang pengumpul menjual kembali biji kopi robusta ke pedagang besar. Di pola saluran pemasaran I dan pola saluran pemasaran II biaya yang dikeluarkan berbeda, yaitu untuk pola saluran pemasaran I biaya yang dikeluarkan meliputi biaya penyimpanan, kuli angkut, pengangkutan/transportasi dan penyusutan. Sedangkan untuk pola saluran pemasaran II biaya yang dikeluarkan meliputi, pengangkutan/transportasi dan penyusutan.

\section{Kegiatan di Tingkat Pedagang}

\section{Besar}

Pedagang besar dalam hal ini berdomisili di Kecamatan Rajadesa dan 
mendapatkan biji kopi robusta dari petani dan pedagang pengumpul Desa Purwaraja dan Desa Tigaherang. Biji kopi robusta yang diperoleh kemudian dijual kembali ke konsumen industri di dalam kota maupun di luar kota.

Proses pemasaran untuk pedagang besar yaitu pedagang besar langsung menerima biji kopi robusta dari pedagang pengumpul dan petani. Sedangkan pedagang besar mengantarkan langsung biji kopi robusta ke konsumen industri di dalam kota dan di luar kota. Dalam hal ini pedagang besar mengeluarkan biaya transportasi dan kuli angkut. Penjualan keluar kota ini dilakukan setiap 5 hari sekali. Dalam satu kali transaksi penjualan ke luar kota sekitar 5 ton.

\section{Kegiatan di Tingkat Konsumen Industri}

Konsumen industri dalam penelitian ini ada satu orang yang terdapat di Kecamatan Rajadesa. Konsumen industri ini mendapatkan biji kopi robusta dari pedagang besar. Biasanya volume pembelian rata-rata berkisar antara 10-25 kilogram per hari. Sedangkan untuk konsumen industri luar kota volume pembeliannya rata-rata berkisar antara 5-6 ton sekali kirim per lima hari sekali.

\section{Analisis Saluran Pemasaran Biji Kopi Robusta}

Analisis data yang dilakukan dalam penelitian pemasaran biji kopi robusta ini meliputi saluran pemasaran, marjin pemasaran, biaya pemasaran, keuntungan pemasaran, farmer's share, dan efisiensi pemasaran.

\section{Saluran Pemasaran}

Kegiatan pemasaran biji kopi robusta di Desa Purwaraja Kecamatan Rajadesa terdapat dua pola saluran pemasaran. Kedua pola saluran pemasaran yang ada melibatkan lembaga pemasaran pada pola saluran pemasaran I, lembaga pemasaran yang terlibat dalam pemasaran biji kopi robusta adalah pedagang besar. Pada pola saluran pemasaran II lembaga pemasaran yang berperan adalah pedagang pengumpul dan pedagang besar sebagai lembaga pemasaran.

Saluran pemasaran yang paling banyak digunakan petani adalah saluran I yaitu sebanyak 17 orang atau 62,96 persen dimana petani langsung menjual ke pedagang besar yang akan dijual kembali oleh pedagang besar ke konsumen industri di dalam kota dan di luar kota. Alasan petani lebih memilih saluran pemasaran I karena proses penjualan biji kopi lebih mudah, baik dalam proses pembelian dan pembayaran terutama petani yang produksi 
biji kopi robusta dalam jumlah besar dan pedagang besar dalam saluran ini dapat menyerap biji kopi robusta dalam jumlah yang lebih banyak jika dibandingkan dengan pola lembaga pemasaran lainnya. Sedangkan alasan petani lebih memilih saluran pemasaran II karena produksi biji kopi robusta lebih sedikit dibandingkan pada pola saluran I dan lebih pada alasan kepercayaan.

\section{Marjin, Biaya, dan Keuntungan}

\section{Pemasaran}

Pada saluran pemasaran I pemasaran biji kopi robusta melibatkan pedagang besar yang berperan dalam penyediaan biji kopi robusta untuk konsumen industri.

saluran pemasaran I pedagang yang terkait adalah pedagang besar. Harga beli pedagang besar dari petani sebesar Rp 19.000. pedagang besar pada saluran pemasaran I ini mengeluarkan biaya pemasaran berupa biaya penyimpanan, biaya kuli angkut, pengangkutan/transportasi dan biaya penyusutan. Pedagang besar melakukan fungsi penyimpanan karena biji kopi robusta pada saluran pemasaran I yang dibeli dari petani akan disimpan terlebih dahulu sebelum dijual. Biaya pemasaran terbesar yang dikeluarkan oleh pedagang besar adalah biaya pengangkutan/transportasi yaitu sebesar
Rp 500 per kilogram. Hal ini dikarenakan pangsa pasar pedagang besar yang berada di luar kota, sehingga dibutuhkan biaya yang besar untuk mendistribusikan biji kopi robusta hingga ke konsumen. Harga jual biji kopi robusta di tingkat pedagang besar adalah Rp 21.000 per kilogram.

Farmer's share pada saluran I adalah 90,47 persen dan besarnya nilai efisiensi pemasaran yaitu sebesar 4,80 persen. Dalam hal ini, untuk saluran pemasaran I dikatakan efisien karena nilai efisiensi pemasarannya sebesar 4,80 persen.

Pada saluran pemasaran II lembaga pemasaran biji kopi robusta melibatkan pedagang pengumpul dan pedagang besar. saluran pemasaran II pada pemasaran biji kopi robusta pedagang yang terkait adalah pedagang pengumpul dan pedagang besar. Selanjutnya pedagang besar biji kopi robusta dipasarkan kepada konsumen. Pada saluran pemasaran II, pemasaran ditujukan untuk memenuhi kebutuhan biji kopi robusta di Kabupaten Ciamis dan luar Kabupaten. Harga beli biji kopi robusta di tingkat pedagang pengumpul dari petani sebesar Rp 18.000 per kilogram sedangkan harga jual biji kopi robusta di tingkat pedagang pengumpul sebesar Rp 19.000 per kilogram dengan biaya pemasaran yang terdiri dari biaya kuli angkut dan 
pengangkutan/transportasi. Sedangkan biaya yang dikeluarkan ditingkat pedagang besar yaitu biaya penyimpanan, kuli angkut, dan pengangkutan/transportasi dan penyusutan. Harga beli di tingkat pedagang besar dari pedagang pengumpul sebesar $\mathrm{Rp}$ 19.000 dan harga jual biji kopi robusta di tingkat pedagang besar sebesar Rp 21.000 per kilogram.

Pada saluran pemasaran II total biaya pemasaran diperoleh dari penjumlahan biaya pemasaran yang dikeluarkan oleh pedagang pengumpul dan pedagang besar. Total biaya pemasaran pada saluran II sebesar Rp 1.590 per kilogram dengan besarnya total keuntungan pemasaran sebesar Rp 1.410. Besarnya total marjin pemasaran pada saluran pemasaran II sebesar Rp 3.000 per kilogram. Farmer's share pada saluran pemasaran II sebesar 85,71 persen dan besarnya nilai efisiensi pemasarannya yaitu sebesar 7,57 persen. Hal tersebut dikatakan efisien karena besarnya nilai efisiensinya berada dinilai 7,57 persen.

\section{KESIMPULAN}

\section{Kesimpulan}

Berdasarkan hasil penelitian dan pembahasan, maka dapat diambil kesimpulan sebagai berikut :

1. Terdapat dua saluran pemasaran biji kopi robusta sampai ke konsumen akhir yaitu :

a. Pola saluran pemasaran I

$\begin{array}{ll}\text { Petani--Pedagang } & \text { Besar } \quad-- \\ \text { Konsumen Industri } & \end{array}$

b. Pola saluran pemasaran II Petani---Pedagang Pengumpu--Pedagang Besar---Konsumen Industri

2. Pada saluran pemasaran I pemasaran biji kopi robusta melibatkan satu lembaga pemasaran yaitu pedagang besar. Besarnya total marjin pemasaran adalah $\mathrm{Rp} 2.000$ per kilogram dengan total biaya pemasaran Rp 1.010 per kilogram sehingga total keuntungan pemasaran sebesar $\mathrm{Rp} 990$ per kilogram. Sedangkan pada saluran pemasaran II pemasaran biji kopi robusta melibatkan dua lembaga pemasaran yaitu pedagang pengumpul dan pedagang besar. Besarnya total marjin pemasaran adalah $\mathrm{Rp} 3.000$ per kilogram dengan total biaya pemasaran sebesar $\mathrm{Rp} 1.590$ per kilogram sehingga total keuntungan pemasaran sebesar $\mathrm{Rp} 1.410$ per kilogram.

3. Besarnya nilai farmer's share atau bagian harga yang diterima petani pada saluran pemasaran I adalah 90,47 
persen dan efisiensi pemasarannya sebesar 4,80 persen. Sedangkan pada saluran pemasaran II besarnya nilai farmer's share adalah 85,71 persen dan efisiensi pemasarannya sebesar 7,57 persen.

\section{DAFTAR PUSTAKA}

Badan Intelijen Negara, 2012. Prediksi dan Tantangan Sektor Pertanian Indonesia Tahun 2013. Terdapat dalam http://bin.go.id/prediksidan-tantangan-sektor-pertanianindonesia-tahun-2013.htm.

Diakses tanggal 10 April 2019. Ciamis.

BP3K Kecamatan Rajadesa. 2018. Laporan Tahunan Kopi Robusta. BP3K Kecamatan Rajadesa Kabupaten Ciamis.

Desa Purwaraja Kecamatan Rajadesa. 2018. Monografi Desa Purwaraja. Desa Purwaraja Kecamatan Rajadesa Kabupaten Ciamis.

Dinas Pertanian dan Ketahanan Pangan Kabupaten Ciamis. 2018. Laporan Tahunan Kopi Robusta. Dinas Pertanian dan Ketahanan Pangan Kabupaten Ciamis.

Dinas Perkebunan Provinsi Jawa Barat. 2017. Laporan Tahunan Produksi dan Permintaan Konsumsi Kopi. Dinas Perkebunan Provinsi Jawa Barat. Terdapat dalam http://.www.dinbun.jabar.go.id.

Diakses tanggal 24 April 2019. Ciamis

Direktorat Jenderal Perkebunan. 2016. Statistik Perkebunan Indonesia : Kopi 2015-2017. Kementerian Pertanian : Jakarta. Terdapat dalam Outlook Kopi 2017 http://www.epublikasi.setjen.perta nian.go.id. Diakses tanggal 24 April 2019. Ciamis

Handayani, S.M dan Nurlaila, I. 2011. Analisis Pemasaran Susu Segar di Kabupaten Klaten. Jurnal Sains Peternakan Vol. 9 (1). Terdapat dalam http://jurnal.uns.ac.id. Diakses tanggal 14 Februari 2019. Ciamis.

Kadir, A. 2005. Analisis Finansial Nira Aren (Arengga Pinnata) Menjadi Produk Gula Merah. Jurnal Penelitian Sosial dan Ekonomi Kehutanan Volume : 2 No. 1, Bogor.

Karya Tani Mandiri, 2018. Rahasia Sukes Budidaya Kopi. Nuansa Aulia : Bandung.

Rosmawati , H. 2011. Analisis Efisiensi Pemasaran Pisang Produksi Petani di Kecamatan Lengkiti Kabupaten Ogan Komering Ulu. (Jurnal) Universitas Baturaja. Malang.

Survei Sosial Ekonomi Nasional. 2017. Perkembangan Permintaan Konsumsi Kopi di Indonesia Tahun 2002-2016. Badan Pusat Statistik : Jakarta. Terdapat dalam http://www.bps.go.id. Diakses tanggal 24 April 2019. Ciamis

Sugiyono. 2010. Metode Penelitian Kuantitatif, Kualitatif, dan $R \& D$. Bandung : Alfabeta.

- 2011. Metode Penelitian Pendidikan Pendekatan Kuantitatif, Kualitatif, dan $R \& D$. Bandung : Alfabeta.

. 2018. Metode Penelitian Kualitatif. Bandung : Alfabeta.

Wibisono, M.S. 2005. Pengantar Ilmu Kelautan. P.T Gramedia Widiasarana. Jakarta. 